\title{
Kernos
}

Revue internationale et pluridisciplinaire de religion grecque antique

21 | 2008

Varia

\section{The fine line of feminine priesthood}

\section{Beate Dignas}

\section{OpenEdition \\ Journals}

\section{Electronic version}

URL: https://journals.openedition.org/kernos/1681

DOI: 10.4000/kernos.1681

ISSN: 2034-7871

\section{Publisher}

Centre international d'étude de la religion grecque antique

\section{Printed version}

Date of publication: 1 January 2008

Number of pages: 312-318

ISSN: 0776-3824

Electronic reference

Beate Dignas, "The fine line of feminine priesthood", Kernos [Online], 21 | 2008, Online since 15

September 2011, connection on 24 August 2022. URL: http://journals.openedition.org/kernos/1681 ;

DOl: https://doi.org/10.4000/kernos. 1681 


\title{
The fine line of feminine priesthood ${ }^{*}$
}

\author{
by Beate Dignas
}

J. Connelly's Portrait of a Priestess, "the first comprehensive cultural history of priestesses in the ancient Greek world" (jacket-copy), is a long awaited book on a much neglected topic. Surprisingly, the character and idiosyncrasies of Greek priesthoods, male and female, have not been explored in any general study that would make use of both the textual and visual evidence at hand. As is the case so often, classical scholars working in their specific fields do not look left and right: those working on Greek literature hardly take into account what epigraphists have to say, the latter are unaware of the findings of archaeologists, and these often could care less about the texts. In contrast, C. makes a plea for using "all existing evidence" (275), and indeed the volume is full of examples and discussion of literary, epigraphic and archaeological testimonies. Obviously, C. is a trained archaeologist, and this shows. While the volume is a gold mine with regard to images and the analysis of these, the epigraphic and literary evidence are treated with much less care (see below), and the integration of the different types of evidence succeeds only partially.

C.'s material and observations range from the late Bronze Age to the fifth century AD, a tremendous scope of a study that raises - and (partly) fulfils - many expectations.

From the beginning, C. leaves no doubt as to her aims: she wants to "challenge longheld beliefs to show that priestesses played far more significant public roles than previously acknowledged" and that they were "not as secluded and marginalized as we have thought" (jacket-copy). This means that the focus on priestesses is a crucial one in the eyes of the author. As reader, one keeps wanting to know whether many of C.'s observations apply to 'women as well as men', 'women as opposed to men' or 'women and may be also to men', and the suspicion that the gendered approach may be misleading creeps up rather frequently. However, the author certainly gets to choose her topic, and in spite of her overall agenda she tries not to overstate her gendered perspective when it comes to everyday features of priesthood. As far as the outcome (or a priori assumption) of the gendered perspective is concerned, the author tackles above all theories of gender oppression. She feels uneasy with regard to any particular strategy of feminist interpretation and would rather replace feminist theory with 'agency theory', emphasise the advancement of family interests and genuine accomplishment through female agency.

The challenge presented by feminine activity and authority in Greek religion is fundamental and has occupied scholars for a long time. Are we dealing with a 'valve' employed to keep the effects of female political oppression at bay? Or are these roles relics and inevitable consequences of a pantheon that consisted not only of gods but also of goddesses who were traditionally served by female cult personnel? Surprisingly, C.'s optimism with regard to 'female agency' in many ways denies the relevance of such questions.

C. covers the subject in ten thematic chapters, followed by an extensive bibliography, and various indices. In all chapters, she draws heavily on J. Turner's Hiereiai: The Acquisition of Feminine Priesthood (unpubl. diss. Santa Barbara 1983) and A. Mantis' study on the iconography of Greek priests and priestesses (1990).

Chapter 1, the Introduction, is either bold or simplistic, and yields examples of a strategy that C. likes to employ in order to smooth over difficult issues. Take for example her

\footnotetext{
* Review article concerning the following book: Joan Breton CONNELLY, Portrait of a Priestess. Women and Ritual in Ancient Greece, Princeton UP, 2007. 1 vol. $21 \times 26$ cm, 415 p., 27 pl., fig. ISBN : 0-691-12746-8.
} 
comments on 'sacred laws', which she makes on the basis of the recognition that sacred laws were - except in subject matter - no different from any other laws. "If things religious were not considered separate from things secular, then the positions of leadership held by priestly women were primary, not peripheral, to the centres of power and influence" (5). Surely, what is at stake here is the character of priestly office, male or female, and the relation between priestly 'power' and decision making processes within the context of civic institutions, complex issues that need careful investigation. Similarly, C. smoothes over the potential methodological pitfalls of the more than broad chronological and geographical scope of her study, which she calls a combination of microanalysis with the longue durée of Braudel (8). As much as we may desire to tell stories from piecemeal information that comes from different places and periods, premises for (female) priesthood changed tremendously over time and emerged and were constituted differently in every community.

The Introduction also includes an unfortunately brief but important section on nomenclature. The priestess as an English term of reference cannot be limited to an investigation of biereiai but has to take into consideration the large variety and flexibility of Greek cult titles. ${ }^{1}$ This is followed by thoughts on the various types of evidence used for interpretation, and the commitment to a careful identification of iconographic signifiers of priestly status (14).

Chapter 2 looks at 'paths to priesthood' and starts off with Aristophanes' famous passage (Lysistrata, 641-647) that sketches a girl's path in the service of several Athenian cults. C.'s comparison with the male cursus of priestly service on Rhodes (28) is not a good idea. Whereas on Rhodes, we see a complex but very idiosyncratic hierarchy of priesthood within the three Rhodian cities, the ritual involvement of Athenian girls at certain points of their adolescence amounts to nothing of the sort - and this is certainly not suggested by the Aristophanic' passage or any other evidence attesting basked bearers or other ritual functions of young girls. ${ }^{2}$ It is rather 'time and age', as C. correctly points out herself, through which the religious identity of the girls in Aristophanes and related evidence is structured (29). The author further links this female religious identity to the mirror image of goddess and priestess, the fact that virgin divinities were served by virgin priestesses, while matronly goddesses such as Demeter were served by married women (30). She adduces a number of examples given by Pausanias. ${ }^{3}$ One wonders how a prevalence of specifically virgin priestesses relates to the epigraphic evidence where qualifications for priesthood may focus on the age and health of the candidate (just as with male priesthoods) but not on the sexual status (later (55) C. acknowledges this for the priesthoods that appear in the Coan sales). The discrepancy may be explained by the fact that 'sacred laws' took the specific marital status of potential priestesses for granted whereas Pausanias likes to illustrate a close relation between ritual service and mythical background, a tendency that $\mathrm{C}$. shares. The same caveat applies to the claim that some priesthoods were reserved for married women. Here, however, C. can back up her claims with epigraphic evidence, primarily from the priesthood of Demeter at Eleusis.

The sections 'requirements for sacred office' and 'methods of acquisition' discuss complex themes rather too briefly, with the exception of the sale of priesthoods on which

${ }^{1}$ Surprisingly, there is no reference to $\operatorname{Thes} C R A$, in particular to vol. 5 on priestly personnel, which would have been very helpful.

2 On the complexity of the Rhodian cursus see B. DignAs, "Rhodian priests after the synoecism," AncSoc 33 (2003), p. 35-51.

${ }^{3}$ With regard to some of these, C. is rather imprecise. Pausanias, e.g. does not tell us that "Marpessa served as priestess of Athena Alea at Tegea until she reached marriageable age" (40) but rather that she was a woman of Tegea who surpassed all other women in daring (VIII, 47, 2-3; 48, 5). In fact, her label as gyne contrasts with the label pais with which the priestess of Athena Alea is described in the same paragraph. 
the reader finds a lot of detail and examples. Although I disagree with C.'s attempt to explain the introduction of the sales in Hellenistic Asia Minor with reference to the waning fortune of important gene who had held inherited priesthoods (45), the author must be right in her overall interpretation of this and other methods of acquisition: the pervasive pragmatism of Greek religion (55).

Chapter 3 focuses on four famous priesthoods, namely that of Athena Polias at Athens, Demeter and Kore at Eleusis, Hera at Argos, and Apollo at Delphi. C.'s characterisation of the priestess of Athena Polias, not surprisingly, rests on the identification of Lysimache, priestess of Athena in the second half of the fifth century, and Aristophanes' Lysistrata (6264). C. eagerly depicts priestesses whose names were household words and whose public roles and individual wit were striking as much as significant. I am tempted to agree. With a similar approach to the interpretation of the priestess of Demeter and Kore at Eleusis, C. follows C. Austin's suggestion that the choral leader in Aristophanes' Thesmophoriazousai was modelled on a historical priestess of Demeter and Kore (65). Capturing the character of this priesthood is difficult indeed. C. shows well that we actually do not know even the most basic parameters of the priestess' terms of office, such as the length of her service or the mode of acquisition. However, C. provides us with a portrait of one of the post-holders, Habryllis, priestess of Demeter and Kore around 150-130 BC (67f). Unfortunately, the priestess' grave marker, which forms an important part of this portrait, is not discussed until Chapter 8 ('Death of the priestess'). Nevertheless, the author cross-references well, and the reader is encouraged to consult other chapters frequently. Only a very different structure of the study would fix the problem, and given C.'s main interest in the iconography of female priesthood, the current chapters make sense.

Testimonies related to the priestesses of Hera at Argos are entirely literary. C. recalls a number of stories that illustrate how problematic generic portraits of priestesses can be.

Finally, the Pythia at Delphi - C. hardly bothers with the distinction between prophetess and priestess but she acknowledges some anomalies, such as life-term office and the background of the Pythia, initially chosen from among the maidens of the local peasantry but later an older woman past the age of fifty. Again, the portrait comes from our literary sources, which C. puts together without much caution. Ultimately, she uses the examples to prove her point 'agency' but one wonders how one can actually compare this 'priestess' to any other. On the whole the chapter is not entirely focussed, eager to bring in Delphic responses (and those from other oracular shrines) regarding priestesses, and then - very oddly - moving on to present the visual evidence for the priesthoods discussed in turn before.

Chapter 4 is on priestly costumes and attributes, providing much food for thought. C. draws on inscribed cult regulations ${ }^{4}$ and literary texts that range from the Homeric epics to the fourth century orators. The question if and how priestly dress was associated with royal and divine costume is absolutely fascinating but C.'s string of examples is not entirely helpful here. If, to take but one of her examples, the barbarians at Marathon in Plutarch's Aristides $(5,7)$ mistook the Eleusinian dadouchos Kallias for a king because of his garb, this does not say very much about the models of Greek priestly dress. With regard to 'sanctuary laws for clothing', wonderful evidence comes from the new Coan inscriptions where, e.g., the priest of Heracles Kallinikos and Zeus Alseios had to wear purple chitones, gold rings, and crowns of leaves when in the sanctuary and while sacrificing, and to wear white at all other times (LSCG $163=$ ICos, ED 89). These are, admittedly, not female priests, but C.

${ }^{4}$ In particular the decree issued in $92 \mathrm{BC}$ on the celebrations of the mysteries at Andania includes detailed prescriptions on ritual dress; C. refers to L. Gawlinski's forthcoming study on the text but omits N. Deshours, Les mystères d'Andania : étude d'épigraphie et d'histoire religieuse, Bordeaux, 2006. 
uses these and other examples to make her general point: sacred clothing mattered. As is well known, female worshippers were often restrained from dressing ostentatiously in sanctuaries. It would be interesting to know if the white garments sometimes prescribed for priests and priestesses were meant to set a good example or to contrast between what was allowed for sacred officials but not for the ordinary worshipper. Here, as in other places, C. does not distinguish clearly enough between female priests and female worshippers in general.

As far as our visual testimonies are concerned, the temple key is the most important attribute of the Greek priestess, and C. places this responsibility in the realm of women in general because, as she says, the woman of the house was traditionally responsible for looking after the door keys (92f). This does not quite square with the role of temple keys as portrayed in our epigraphic evidence to which there is not a single reference in this important section. It would appear that an entirely gendered reading of the signifier is at best an exaggeration. Male and female priests could be entrusted with the task of opening and closing the temple; in addition, they shared the authority over treasury keys with local magistrates, and the witnessed opening of the treasuries gave meaning to the signifier, pointing to the - albeit audited - authority of the priest(ess). However, C. is right that the representations of female priests use the key as the most common signifier. Accordingly, the chapter features beautiful examples of key bearing priestesses, to name but one the fourth century honorary relief depicting Athena Parthenos supporting a winged Nike on her outstretched hand, who is in turn crowning a key bearing female figure, no doubt Athena's own priestess (96, fig. 4.7). Even more prolific than the reliefs are vase paintings. Here, C. points to the link between the signifier 'key' and the theatre. Her observation that text and visual language can but need not overlap is important, and the author assumes that (and one indeed wonders to what extent and with what consequences) the theatrical model was influential in later Athenian/South Italian and ultimately our own perception of female priestly responsibilities.

C. is convinced that 'divine imitation' was one of the roles of Greek priests and priestesses. Goddesses, such as Demeter in Callimachus' Hymn to Demeter impersonated priestesses and priestesses imitated the goddesses they served. C.'s examples illustrating this understudied topic are exclusively late, i.e. Roman period, but one could enhance her case with further and earlier ones. Antiochus III, e.g., prescribed that the priestesses of his Queen Laodicea at Iasus wear golden wreaths showing the image of the queen (IIasos 4B, 1. 79-81). He modelled his idea upon a tradition of priestly diadems carrying the symbols or image of the deity they were serving. These again may go back to the crowns of the divinities themselves which were frequent and often integral parts of cult images. ${ }^{5} \mathrm{C}$. calls all this 'sacred drama' (107) and refers to the famous examples of Alexander the Great and Marc Antony entering places in the guise of Dionysus or other deities. One wonders if the author is making any point here, for she ends the list of stunning examples with the throwaway remark, "By the Hellenistic period the lines between divinity and mortal became increasingly obscured, particularly with the advent of ruler cult" (108).

As is characteristic of C.'s work, in spite of the 'staccato' headings and sections throughout the work, one theme seamlessly 'flows' into another; divine impersonation thus leads her to discuss the phenomenon of 'offering gods', scenes that show divinities pouring libations and offering sacrifices at altars. C. raises the possibility (with good arguments that

\footnotetext{
${ }^{5}$ C. does refer to W. Burkert, Greek Religion, $97 \mathrm{f}$ and could draw on U. KRON, "Götterkronen und Priesterdiademe. Zu den griechischen Ursprüngen der sog. Büstenkronen,” in N. BASGELEN, M. LUGAL (eds.), Armagani. Festschrift für Jale Inan, 1989, p. 373-90; see also B. DignAs, "Porter la couronne d'un dieu : titre civique, charge religieuse, pouvoir ou fardeau?,” Kernos 20 (2007), p. 173-187.
} 
could be supported by further evidence) that these figures were, after all, not the deities themselves but their priestesses engaged in ritual mimesis (108-115).

The summary to the chapter falls flat but it would be too much to expect a synthesis of what is an incredibly difficult theme.

Chapter 5, entitled 'The Priestess in the Sanctuary', opens with the inscribed statue base of Philtera, priestess of Athena Polias during the third quarter of the second century BC (117). C. translates 'this Philtera was established as your servant' but the verb i $\delta$ Qú $\theta \eta$ must refer to the setting up of the statue of Philtera so we should rather read, 'this (statue of) Philtera as a sacred servant has been set up in your temple' - with which C. should be pleased because we see how the iconography is expected to include clear signifiers of priesthood. In general, the vocabulary of such texts would deserve more attention. It seems very odd that the term agalma appears only four times in the book, and its discussion is dismissed more than briefly on 132, "Agalma translates as 'pleasing gift', and could mean a statue or some other kind of ornament". The chapter surveys statues of priestesses geographically at this point and ends with examples from Aulis in Boeotia. The provenance and dates may vary too grossly for any generalisation but $C$. has a point when she reminds us that "images of priestesses inhabited their sacred space long after their years of service had ended"; the impressive number of statues with or without dedicatory inscriptions honouring past and present priestesses is an important aspect of priestly presence in sacred space. In her conclusion C. speculates whether draped female statues in classical times and after were descendants of the archaic korai (163). In line with her overall argument she carefully proposes 'those who held special agency within the sanctuary' as a possibility. ${ }^{6}$

Chapter 6 is called 'The Priestess in Action' and, unsurprisingly, looks at 'women's agency in ritual'. Once more, C. does not distinguish clearly between women's roles in general and those of cult officials, which may be owing to the fact that our visual representations often do not allow for this distinction, e.g. when we see a female figure pouring a libation. Sacrifice is, of course, a central theme in this chapter. C. is adamant that women presided over sacrifice and that the butchering of the sacrificial victim, a male prerogative, should not be seen as superior to female agency. The argument is thin and a little contrived here. While playing down the role of priests in general ("a priest was not even necessary") and pointing to the subservient role of the hired mageiros, the author emphasises female agency as paramount ("This text [LSAM 48] explicitly places the victim's flesh in the hands of the female sacrificer," 182). The last heading, 'Benefactions' is somewhat misplaced here but certainly an important section. C. provides the reader with a long list of examples and the general impression that "Nowhere did women give more generously than in Hellenized Asia Minor." A more analytical approach that tries to establish the links between priesthood and benefaction, objects, motivation and historical change remains a desideratum; however, lack of time and space may have prohibited C. from analysing the types and contexts of female benefactions more closely.

Chapter 7 on 'Priestly Privileges' is a fascinating chapter that should be linked to the previous section on benefactions. C. does not only look at priestly apometra and hierosyna but also discusses access to sacred space and public honours such as crowns and the right of proedria, as well as official decrees that sanctioned a priestess' right to defend her privileges. Unfortunately, C. is very brief and cursory and for no obvious reason treats this important aspect under the headings 'inscriptions' and 'literary evidence' respectively. She comes to the

${ }^{6}$ Earlier $(126 ; 129)$ she interprets the archaic korai as cult agents proudly showing off their specific functions within the ritual; see now also R. VAN DEN HOFF, "Images and prestige of cult personnel in Athens between the sixth and the fourth centuries BC," in B. DignAS, K. TrAMPEDACH (eds.), Greek Priests and Cult Officials from Homer to Heliodorus, Harvard UP, 2008, p. 107-141. 
somewhat hyperbolic conclusion that priestesses were 'at the center of legal affairs' and possessed 'a unique agency in the very public arena of the law.' (217) The following section on 'authority' is even more a mix and match of examples given by Herodotus for the archaic period paired with details in late Hellenistic advertisements for the sale of priesthoods. There is no differentiation between the Delphic Pythia and local priestesses, disregarding the paramount difference that the former was called on for arbitration and advice whereas the latter would have been given guidelines of office devised for (also her own) compliance, albeit as a matter of negotiation between incumbent and polis.

Chapter 8 ('Death of the Priestess') abounds with beautiful illustrations. Apparently, grave markers showing priestesses holding a temple key are rather generic in type. C. suggests a stock type the existence of which would attest to a widespread phenomenon of honouring deceased women in their role as priestesses. For the Hellenistic period, we need to distinguish between on the one hand the more modest Attic kioniskoi, which indicated priesthood by the combination of a simple key decorated with small ribbon, and on the other hand the much more elaborate funerary reliefs of Asia Minor, where we find divine attributes or the depiction of servants carrying symbols of the deity served by the deceased priestess. It is problematic to juxtapose, as C. does, the visual representations that are not accompanied by words with epigrams praising deceased priestesses to make up for "the sentiment lacking in the grave relief" (250). However, there is the monument set up for Menophila at the end of the second century BC at Sardis - the inscription straightforwardly explains the iconography, and although priesthood is not mentioned explicitly the text refers to Menophila's arche as symbolised by the wreath she is wearing. Is this, however, the case with all wreaths depicted on such monuments? Rather than symbolising the priestly crown, many may simply reflect public recognition and honours.

Priestesses, although this was extremely rare for any woman, could receive public burial. C. observes that "by the Hellenistic period, it was an honour particularly associated with priestesses, benefactresses, and civic-office holders" (224). This raises the question if these women were honoured in their role as priestesses or as benefactresses, who, often beyond death, had earned honours for their euergetic activities - priesthood may not have been the reason for honours but itself an honour and reward (which, of course, then stimulated benefactions again). These difficulties in reading both text and image become clear in C.'s last example, the honorary decree for Berenike, who is crowned by the city of Syros at her burial (256f). She is praised for her record of public service as well as role as mother. Priesthood is one of many aspects.

Chapter 9 moves on to contrast the burial of a holy Christian woman, Melania the Younger, who died in AD 439, with the "lavish funerals for Greek priestesses, state events in which the bodies of the deceased were draped in expensive purple and carried through the streets in public funerary processions" (260). This image of the Greek priestess is certainly exaggerated, if not false, and has not been established by Chapter 8 at all. However, C.'s case-study of Melania also attempts to find the common roots and characteristics of pagan and Christian female worshippers. C. traces the traditions of euergetism and private cult associations, philosophical henotheism, and the prevailing model of the organisation of the Greek household, which, as the author claims, bore tremendous influence on the Early Church

Finally, Chapter 10 ('Conclusions'), which is all about the wider message of the book: the agency of women and the flaws of a feminist approach. C. goes through her main themes one by one and interprets 'the glass as half full' rather than 'half empty'. Her points are not as new as she claims and the enemy not as real as she would like. No scholarship produced within the last thirty years has deprived women of their active role in Greek religion, or has 
denied female euergetism, and many scholars have indeed followed David Lewis' suggestion to take Aristophanes' Lysistrata as modelled upon the priestess of Athena Polias, Lysimache. The term 'agency' is therefore a rather overused term in the volume. C.'s simple yet forceful style is admirable but also produces sentences such as this, "The cumulative force of these arguments strips feminine sacred service of a measure of its dignity and discounts the potency of female agency with the totality of Greek cult and culture" (20).

Epigraphists will not entirely be happy with what they find in the Portrait of a Priestess because the presentation and translation of inscriptions leaves much to be desired. More than once, there are different translations of the same passages in different sections of the book (e.g. the inscription on the statue base for Lysistrate, propolos of the Eleusinian goddesses, which on p. 132 is quoted as "she does not spare her resources but is unstinting to the gods to the best of her ability" but on p. 193, in the context of benefactions, as "she does not spare her property but makes abundant gifts to the gods according to her wealth"). When C. talks about the spectacular text from Magnesia recording the burial of three Maenads who had been fetched from Thebes in order to set up Dionysiac thiasoi in the city the translation does not cover the whole Greek text printed. In other cases the translations are simply flawed. I give but a few examples. When presenting the famous Cnidian dedication made by Chrysine, mother of Chrysogone ${ }^{7}$, in 1.4 the author translates the plural

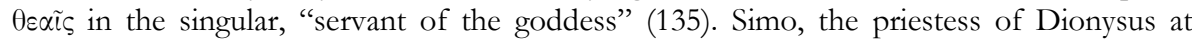
Erythrae is $[i<\varepsilon>] \varrho \varepsilon ́ \alpha$ $\pi \varrho o ̀ ~ \pi o ́ \lambda \varepsilon \omega \varsigma$, which, in particular given the Dionysiac context, cannot be translated as 'priestess of the city' (139). Myrrhine, priestess of Athena Nike, was not 'chosen by a fortunate lot' (176). ${ }^{8}$ Mneso, daughter of Kritodemos of Thorikos, in C.'s translation is 'wife of Asklepiades Berenikidou' (243). The honorary decree in honour of Berenike from second/ third century AD Syros (256f) features line breaks at first, then continuous text, with no hyphens where words are split, and has a number of wrong accents. Such carelessness is also visible in typoes. On page 362, e.g., there are five mistakes (a left out article, Maguire instead of Magie, Archeologio instead of Archeologia, imperantihus instead of imperantibus).

It is easier to express misgivings and to criticise than to do a better job oneself, and I apologise to the author for sounding too critical of a study that is in many ways a splendid achievement and can serve as a starting point for many in-depth studies of Greek priesthood. In an extremely readable way, C. explains her observations and important aspects of Greek religion and priesthood. In particular, when it comes to the main focus of the book, the material culture illustrating female involvement in religious matters, C. is eloquent as well as conscientious and portraits of priestesses come to life beautifully. The author reminds those of use who tend to focus on written testimonies that imagery, in particular imagery displayed in sacred space, tells us a lot about the (self-)representation of priestesses and was a powerful medium that addressed contemporaries and future generations directly. Ultimately, I would not want to miss C.'s book on the bookshelf or even, given its superb aesthetic qualities, on the coffee table.

Somerville College

Woodstock Road

OXFORD OX2 6HD

E-mail: beate.dignas@some.ox.ac.uk

\footnotetext{
${ }^{7}$ See with a re-interpretation K. RigSBY, “Chrysogone's mother," MH 60 (2003), p. 60-64.

${ }^{8}$ The epitaph could have been interpreted more fruitfully. It looks as if the priestess' name alludes to the myrtle of which her priestly crown would have been made of; see S. PRICE, Religions of the Ancient Greeks, Oxford, 1999, p. 176.
} 